
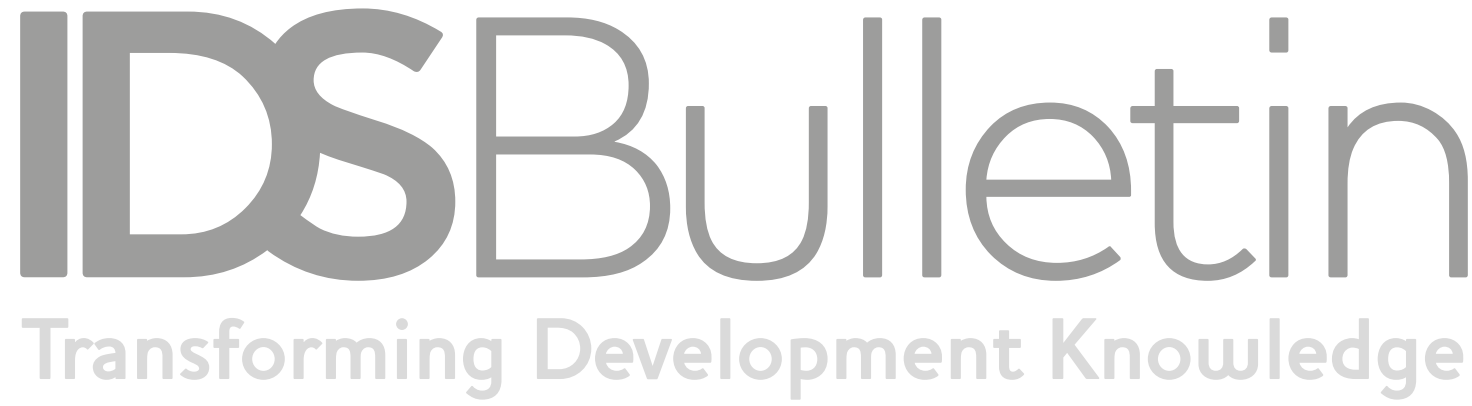

Development Knowledge

Volume 50 | Number 4 | December 2019

\title{
THE BELT AND ROAD INITIATIVE AND THE SDGs: TOWARDS EQUITABLE, SUSTAINABLE DEVELOPMENT
}

\section{Editors Gong Sen, Melissa Leach and Jing Gu}

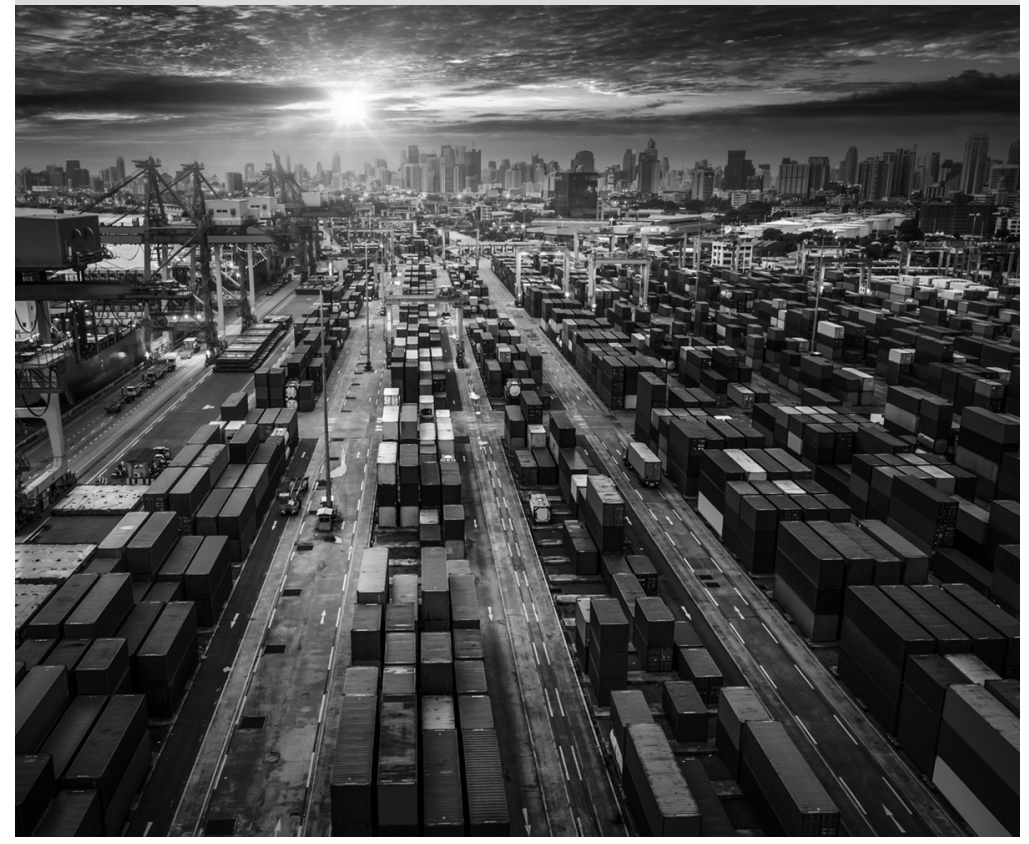


Notes on Contributors

Introduction: The Belt and Road Initiative and the Sustainable Development Goals: Opportunities and Challenges

Jing Gu, Hannah Corbett and Melissa Leach

The Digital Silk Road and the Sustainable Development Goals

Gong Sen and Li Bingqin

Green Belt and Road Initiative Environmental and Social Standards: Will Chinese Companies Conform?

Jiang Xiheng

Aligning the Belt and Road Initiative with Myanmar's Sustainable Development Plan: Opportunities and Challenges

Zhou Taidong

The Belt and Road Initiative and Africa's Sustainable Development: $A$ Case Study of Kenya

Jing Gu and Shen Qiu

Sino-Greek Economic Cooperation: COSCO's Investment in the Port of Piraeus

Liu Qianqian and Polyxeni Davarinou

The China-Pakistan Economic Corridor: A Case Study

Mustafa Hyder Sayed

Will the Belt and Road Initiative Boost Least Developed Countries Towards Sustainable Development?

Namsuk Kim

Glossary 


\title{
Green Belt and Road Initiative Environmental and Social Standards: Will Chinese Companies Conform?*†
}

\author{
Jiang Xiheng ${ }^{1}$
}

\begin{abstract}
The Belt and Road Initiative (BRI) proposed by China in 2013 has been seen as one of the most ambitious initiatives to enhance infrastructure connectivity within and across countries. However, the initiative has attracted some controversy over the last five years. On the one hand, it is commended for responding to the urgent needs of many developing countries in building up basic energy and transportation infrastructures; on the other hand, it is questioned for the environmental, social, and fiscal impacts brought by large-scale infrastructure projects. The Chinese government proposed a green BRI in 2016. It is critical to understand whether greening the BRI will be translated into action, especially by the Chinese companies who fund and construct BRI projects. This article examines the pressures and incentives Chinese companies face alongside their capacity to green BRI projects. Gaps are identified in these three aspects and policy recommendations proposed to the key stakeholders.
\end{abstract}

Keywords: Belt and Road Initiative, greening, environmental and social standards, Chinese companies.

\section{Introduction}

China's initiative to build the Silk Road Economic Belt and the twenty-first century Maritime Silk Road, in abbreviation the Belt and Road Initiative (BRI), aims at common development through enhanced connectivity in policies, facilities, trade, investment, and people-topeople bonds (Xinhua News 2015). China believes that infrastructure is the foundation of economic growth and enjoys competitive funding, capacity, and technology advantages in the building of infrastructure. According to some recent estimates, the global infrastructure investment needed to support the currently expected rates of economic growth is above US\$3.3tn annually (McKinsey Global Institute 2016), while Asia alone needs US\$1.7tn (ADB 2017: vii). While the infrastructure 
need is increasing, there are fewer infrastructure projects with private participation in emerging markets and developing countries. The 242 projects recorded in 2016 is 27 per cent less than the 334 projects registered in 2015, and a little more than half the average number of projects during the years 2011-15 (World Bank 2017).

Many countries face significant infrastructure investment gaps and are therefore keen to participate in the BRI (WWF 2018). According to the World Bank report published in April 2019, countries that lie along the Belt and Road corridors are ill-served by existing infrastructure and by a variety of policy gaps, and as such they under-trade by 30 per cent and fall short of their potential foreign direct investment (FDI) by 70 per cent (World Bank Group 2019). Since its launch, BRI investments have largely focused on infrastructure. While different estimates for BRI projects can be found, the Chinese Ministry of Commerce records that from 2014 to 2017, the number of BRI projects and the size of the investments are growing at a rate of 18 per cent and BRI investments reached US\$143bn in 2017, which is around one third of the total global infrastructure investments (ibid.). Among the newly contracted projects in 2017, three quarters of them are in the power and transport sectors, but the BRI portfolio is expected to shift towards manufacturing and urban infrastructure development in the near future (ibid.).

Given such scale and structure, BRI investment inevitably faces high environmental and social risks. Many BRI countries in Central Asia and Southeast Asia have vulnerable ecological and social systems, which further magnify risks. In addition, meeting global climate change targets requires rapid progress toward decarbonisation, creating a risk of stranded assets to fossil-fuel infrastructure. Negative environmental and social impacts have the potential to delay or stall projects, which can lead to major financial losses. As Chinese companies have increased their footprints abroad, they are being held accountable for environmental and social outcomes, just like multinational companies from other countries.

Over the past decades, China has paid increasing attention to ecological preservation and environmental protection, both in domestic development and overseas investment. China's president, Xi Jinping, has repeatedly stressed the importance of building an ecological civilisation both in China and globally. In 2016, he called for a Green Silk Road (State Council Information Office of the People's Republic of China 2016), and in 2017 he proposed an international coalition for a green BRI and a big data service platform on ecological and environmental protection (Xinhua News 2017). Both the coalition and the big data platform were launched in April 2019. The coalition convened Chinese and international stakeholders for dialogue, knowledge-sharing, and technology transfer, structured under ten thematic partnership groups (International Cooperation and Exchange Center of the Ministry of Ecology and Environment 2019). The data platform provided data on the ecological conditions; environmental laws and regulations; business 


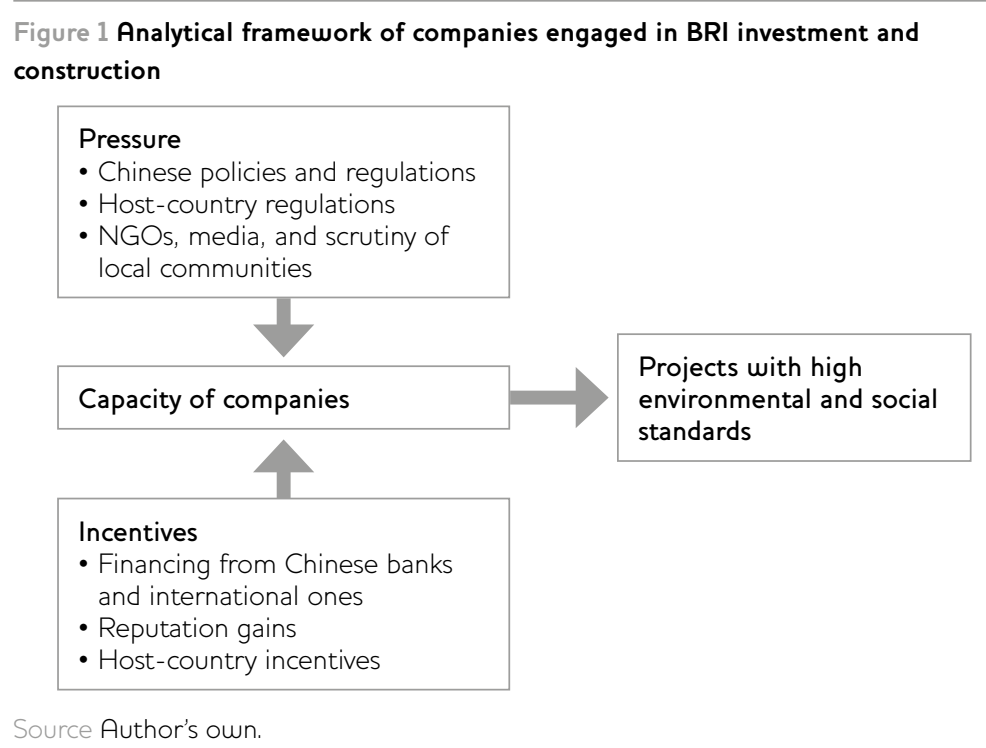

opportunities in BRI countries with the help of the internet; big data; and satellite remote sensing (ibid.).

Will Chinese companies follow the higher environmental and social standards in the context of a greening BRI, as advocated by the Chinese government? How can all stakeholders including the Chinese government, host countries, and international institutions make green investment happen at a faster speed? Finding answers to these questions is needed in order to achieve the Sustainable Development Goals, as well as for the success of the BRI as a contribution to global development. This study situates these questions in an analytical framework in order to examine the key determinants, the status quo, and the gaps, and to give policy recommendations for the key stakeholders.

\section{Analytical framework}

The analytical framework in Figure 1 focuses on companies that are the key actors in direct infrastructure investment and construction activities, towards higher or lower environmental and social standards. These include large Chinese state-owned enterprises (SOEs) and private companies that invest in or construct infrastructure projects abroad. To encourage companies to adopt and build up capacity for higher environmental and social standards, the right pressure and incentives must be put in place, as shown in the framework.

There are various sources of pressure on Chinese companies to green investments and construction activities. These include the evolving green BRI policy and regulatory framework articulated by the Chinese government, more stringent regulations, and higher environmental and social safeguard standards in host countries, as well as increasing scrutiny from non-governmental organisations (NGOs) and local communities. 
The overriding incentive for investors is to find projects that provide a return on investment. They are thus sensitive to financing opportunities around the BRI, as well as more indirect factors such as reputation gains and host-country policy incentives. Among which, the role of financing incentives is the key one and thus is the focus of analysis.

Chinese companies vary significantly with respect to their capacity for higher environmental and social standards. Some major ones are the most competitive contractors on the global infrastructure market while some minor ones are short of capacity.

\section{Pressure for Chinese companies to follow high environmental and social standards \\ 3.1 The evolving green BRI policy and regulatory framework}

Since 2015, official BRI documents have increasingly stressed the importance of greening infrastructure investments. This framework provides a set of guiding principles, although it puts the onus of operationalising them onto investors and project implementers. However, over time, there is a trend towards more precise rules that could provide a baseline to more specific and binding regulations in the future.

The first official document illustrating what the BRI is and how it is expected to be carried out is the Vision and Actions on Fointly Building Silk Road Economic Belt and 21st-Century Maritime Silk Road, published jointly in March 2015 by the National Development and Reform Commission (NDRC), the Ministry of Foreign Affairs (MFA), and the Ministry of Commerce (MOFCOM) (Xinhua News 2015). This document asserts that the BRI will follow the principles of consultation, joint efforts, and shared benefits, as well as market rules and international norms. It also states that the BRI will 'strengthen the green and low-carbon construction and operation management of infrastructure, taking full account of the impact of climate change during construction' (ibid.).

In order to mainstream ecological civilisation in the BRI and imbed sustainability into the efforts of policy coordination, infrastructure connection, trade, and investment, the Guidance on Promoting Green Belt and Road was issued by the Ministry of Environmental Protection which became the Ministry of Ecology and Environment (MEE) in March 2018, jointly with the MFA, the NDRC, and the MOFCOM in 2016. This policy paper promotes the adoption of green concepts in all BRI activities and notes the importance of international collaboration and government-enterprise coordination to ensure implementation results (Belt and Road Portal 2017b).

This framework received further specification in 2017. In order to further strengthen cooperation on eco-environmental protection and enable eco-environmental protection to serve, support, and guarantee the Belt and Road construction towards environment-friendly routes, the Belt and Road Ecological and Environmental Cooperation Plan was enacted in May 2017 (Belt and Road Portal 2017c). It translates the guidance 
of green BRI into more detailed policies. It emphasises commitments to enhanced guidance to further green corporate behaviour by implementing the Guidance on Promoting Green Belt and Road, and the Guidelines for Environmental Protection in Foreign Investment and Cooperation jointly released by the MOFCOM and the MEE (ibid.). It also stresses the implementation of the Initiative on Corporate Environmental Responsibility Fulfilment for Building the Green 'Belt and Road' announced by 19 key state enterprises (ibid.).

Green concepts and environmental protection requirements have also been integrated into other BRI policies. In the Vision and Actions on Energy Cooperation in Fointly Building Silk Road Economic Belt and 21st-Century Maritime Silk Road, commitment is made 'to attach great importance to the issue of environmental protection in the process of energy development, and strive to encourage the efficient development and utilisation of clean energy and technology transfer as well' (Belt and Road Portal 2017d).

In December 2017, the Code of Conduct for Chinese Private Investors was jointly published by the NDRG, the MOFCOM, the People's Bank of China (PBOG), the MOF, and the All-China Federation of Industry and Commerce as a BRI policy (Belt and Road Portal 2017a). It includes one chapter on environmental protection and resource conservation. In particular, there is one notable excerpt: 'In countries where there is no environmental laws and standards, the environmental standards of international organisations and multi-lateral organisations could be adopted' (ibid.). With increasing specifications to fill the gaps of regulation, this shows evident progress in terms of policy guidance. Past policies requested investors to observe the laws and standards of host countries and use Chinese standards in such cases where no local laws exist. In addition, in the Action Plan on Standardization Connectivity 2018-2020 (Belt and Road Portal 2018), one of the key actions is designated to enhance international collaboration on standardisation in energy saving and environmental protection to serve the green BRI.

The Second Belt and Road Forum for International Cooperation held in April 2019 set clear directions for BRI development after its first five years. With high quality as the theme of the Forum, the event emphasised the principle of 'extensive consultation, joint contribution and shared benefits', and made clear the approaches of 'open, green and clean cooperation' for the goals of high standards, a people-centred approach, and sustainability (Ministry of Foreign Affairs of the People's Republic of China 2019a). Consensus was achieved that support for the United Nations (UN) 2030 Agenda for Sustainable Development (2030 Agenda) should be made an integral part of Belt and Road cooperation, and that economic growth, social progress, and environmental protection should be pursued in a balanced way (Ministry of Foreign Affairs of the People's Republic of China 2019b).

Xi Jinping made commitments on transparency and clean governance in pursuing Belt and Road cooperation and zero tolerance for 
corruption. He said that 'everything should be done in a transparent way' and that '[China] will adopt widely accepted rules and standards while the laws and regulations of participating countries should also be respected' (Ministry of Foreign Affairs of the People's Republic of China 2019a). Green finance was repeatedly mentioned, including in the context of enhancing collaboration on the Paris Agreement. In the joint communiqué, commitments are made to 'build high-quality, reliable, resilient and sustainable infrastructure' and it is emphasised that 'high-quality infrastructure should be viable, affordable, accessible, inclusive and broadly beneficial over its entire life-cycle, contributing to sustainable development of participating countries and the industrialisation of developing countries' (Belt and Road Portal 2019a). To achieve the goal, parties will work together in line with China's national legislation, regulatory frameworks, international obligations, applicable international norms and standards (ibid.).

In addition to this framing, a few key concrete measures launched by China and participating countries and organisations continued the trend towards greater specificity in rules and processes around greening the BRI. The BRI International Green Development Coalition was launched with ten thematic groups and over 120 participating international organisations, government ministries, and NGOs, thinktanks and businesses. This group serves as an important forum for future discussions on greening the BRI. In addition, major financial institutions from China, the UK, France, Singapore, Pakistan, the UAE, Hong Kong SAR, and other countries and regions signed up to the Green Investment Principles for Belt and Road Development (Green Finance 2019). To improve cooperation in project preparation and implementation and to promote projects that are investable, bankable, economically viable, and environmentally friendly (ibid.), the Ministry of Finance of China in collaboration with the Asian Infrastructure Investment Bank (AIIB), the Asian Development Bank (ADB), the European Bank for Reconstruction and Development (EBRD), the World Bank Group, the Inter-American Development Bank (IDB), and a few other financial institutions jointly established the Multilateral Cooperation Center for Development Finance (Ministry of Foreign Affairs of the People's Republic of China 2019c).

\subsection{The increasingly stringent regulations and growing capacities of host countries}

Alongside a growing emphasis on sustainability in the framework of the BRI, policies of host countries can serve as a powerful driver for greening infrastructure investments. The Chinese government requires overseas investors to abide by the laws and regulations of the host countries, although monitoring and enforcing this requirement is a difficult challenge. BRI countries in Central and Eastern Europe are generally EU members and apply high environmental and social standards to investments. A number of African countries such as Nigeria, Kenya, and others are setting up an environmental safeguard reporting system for foreign investors. Many BRI countries are 
enhancing their legal requirements for labour protection, technology transfer, and local share of benefits. Chinese investors will face increasingly complex due diligence and compliance management challenges (UNDP 2017).

In addition, policy coordination and capacity building under the BRI framework can help some BRI countries with weak legislative and executive capacities build up their capacities to manage environmental risks. China signed Memoranda of Understanding (MoUs) with the United Nations Environment Programme (UNEP) and over 30 countries for environmental protection under the green BRI and launched the Green BRI Envoy Plan, which provided training courses for over 2,000 officials engaged in environmental protection (MEE n.d.). The Green Finance Leader Programme was launched in 2018 and provided knowledge-sharing seminars for 120 regulators from $35 \mathrm{BRI}$ countries (IFC 2018b). With the BRI International Green Development Coalition and the ecological big data platform becoming operational, regulatory coordination, capacity building, and technology transfer can further improve the regulatory environment in BRI countries.

\subsection{Growing pressure from NGOs, the media, and local communities}

International and local NGOs, the media, as well as local communities in host countries can have a strong influence on the operations of infrastructure projects. In addition to a fragile ecology and sensitive environment, many countries along the Belt and Road are confronted with complex geopolitical and social challenges. The majority of BRI projects are large construction projects with significant environmental and social impacts. Investors must pay careful attention to local concerns and priorities if those investors should wish to acquire a social licence to operate over the lifespan of a project. For example, a recent poll of public opinion in six BRI countries showed that the public prefer renewable power investments to fossil-fuel investments by a ratio of two to one, and are much more likely to support foreign investment for renewable projects over traditional power infrastructure (Littlecott and Hawkins 2019). While it is the host-country government that ultimately decides on its preferred power infrastructure, with Chinese companies acting as contractors winning bids and implementing projects within the contracted budget, there is some scope for greater accountability of Chinese companies within this process.

Many international and local media, and environment and human rights organisations are also closely watching these projects. Any negative environmental impact, land dispute, or labour issue can be immediately exposed to reach a large domestic and international audience. A number of projects in Southeast Asian and African countries have been stalled or cancelled due to these factors. A well-known case is the Myitsone Dam in Myanmar which was stalled in 2011 after two years of construction, impacting the Chinese company that won the project through bidding, and with significant losses. This case helped Chinese companies understand that environmental 
regulation, social impact, information disclosure, political uncertainty, public opinion, and the capacity of Chinese investors are all factors for risk management in overseas infrastructure investment.

Furthermore, some negative cases have been turned into bloated and anecdotal stories in the media and believed by the local people. An often-told story is that Chinese companies predominantly employ Chinese workers, depriving locals of potential jobs, and where locals are employed, they are paid low salaries and offered little training. In a recent study coordinated by the School of Oriental and African Studies and the London School of Economics, researchers compared Chinese and non-Chinese manufacturing and construction companies in Angola and Ethiopia, two of the top African destinations for Chinese direct investment. Fieldworkers studied 76 companies over a four-year period, 31 of them Chinese, which included interviewing 1,500 Angolan and Ethiopian workers (Pilling 2019). The study found that the negative stories about Chinese companies are mostly untrue. It showed that Chinese companies generally employ just as many local workers as non-Chinese companies, pay them more or less the same, and train them to similar standards, though usually less formally (ibid.). In light of the existing bias, and in order to change this grim portrayal of Chinese companies, more evidence-based study is needed. At present, compared with their US and European peers, Chinese companies have to outperform in order to get similar recognition.

\section{Financing incentives that promote environmental and social safeguards}

The financial sector can play a key role in delivering sustainable infrastructure by requiring best practices in infrastructure planning, design, construction, and operation (WWF 2018). Over the past decade, Chinese financial regulators have adopted a variety of standards regarding green finance. This growing regulatory framework refers to and borrows from international standards. More research is needed to understand how investors are operationalising this framework in practice. Going forward, greening the BRI will require this system to continue strengthening in financial institutions, both on paper and in practice.

\subsection{China's green financing policies}

In 2007, the PBOC, the Chinese Banking Regulatory Commission (CBRC), and the Ministry of Environmental Protection (MEP - now the MEE) jointly issued the Green Credit Policy and called on banks to take environmental impact and energy efficiency into consideration when making lending decisions. In order to play the role of financial institutions in implementing state council policies enacted in 2011 on promoting energy efficiency, emission reduction, and environmental protection, the CBRC issued the Green Credit Guidelines in 2012 (Fa 2012). It provided the operational guidance on how to implement green banking in three aspects which: support a green, low-carbon, and low-waste economy; manage environmental and social (E\&S) 
risks; and improve the environmental and social performance of financial institutions themselves. In this document, E\&S risks were defined as 'potential impact and risks brought to the environment and communities by banks' clients and their primary supply chains through construction, production and operational activities' (IFC 2018b: 7). The development of $\mathrm{E} \& \mathrm{~S}$ risk ratings and the identification of high $\mathrm{E} \& \mathrm{~S}$ risk clients was also explicitly required (ibid.). Three years later, the policy guidance was developed into detailed indicators. The CBRC began to impose Green Credit Key Performance Indicators and E\&S risk reporting obligations on banks in 2015.

With regard to its convergence with international good practices, the Green Credit Guidelines encourage banks to adopt good practices and international standards or act up to the standards in essence. This document has greatly enhanced the awareness of Chinese financial institutions regarding green finance and the corresponding internal management systems have been building up in all financial institutions, though they might vary in progress. To date, three banks are signatories to the Equator Principles (Equator Principles Association 2019), three banks are signatories to the UN Global Compact (UNGG), and five investment managers have signed the UN Principles for Responsible Investment (UNPRI) (IFC 2018b).

This green finance regulatory framework also covers overseas investment. It requests that banks should strengthen E\&S risk management for proposed overseas projects, and ensure that project sponsors are compliant with local environmental, land, and health and safety laws and regulations in the project country or region. Banks are also required to publicly commit to adopting relevant international best practices or standards for the proposed overseas project or ensure that the proposed project is consistent with international best practices in essence (China Banking and Insurance Regulatory Commission 2019).

\subsection{International green financing policies compared to Chinese ones}

The Performance Standards on Environmental and Social Sustainability of the International Financial Corporation, World Bank Group (IFCPS) is a widely recognised international standard for advanced economies. It has been adopted by, or has influenced the development of, all multilateral development banks (MDBs) and Organisation for Economic Co-operation and Development (OECD) countries. Comparing China's Green Credit Guidance (GCG) and the IFCPS shows convergence in many areas but also variation in emphasis on information disclosure and compliance (Table 1). ${ }^{2}$ The GCG policies are, more or less, guidelines that are soft in enforcement provisions and information disclosure to the public, although IFCPS standards are encouraged by the policies.

To improve regulatory mechanisms for enhanced implementation, in August 2016, the PBOC and six other ministries jointly issued the Guidelines on Building a Green Finance System (Xueqing 2016) to enhance 


\section{Table 1 Comparison between IFCPS and China's GCG policies}

\section{IFCPS standards GCG policies}

1 Assessment and management of environmental and social risks and impacts

- More stringent standards of accountability of financial institutions in reporting to regulators but less requirements for information disclosure.

2 Labour and working conditions

3 Resource efficiency and pollution prevention

4 Community health, safety, and security

5 Land acquisition and involuntary resettlement

6 Biodiversity conservation and sustainable management of living natural resources

7 Indigenous peoples

8 Cultural heritage
- Energy consumption, pollution prevention, health, safety, land acquisition and resettlement, ecological protection, and climate change are covered.

- Implementation requirements are not made in detail.

- Self-reporting is requested.

- Compliance to both local laws and regulations as well as Chinese laws and regulations are requested.

- IFCPS standards are encouraged.

institutional innovation in the administration of environmental and social factors in outbound Chinese investment. It also calls for enhanced environmental information disclosure; for instance, to incorporate the environmental information of enterprises, including environmental violations, into the financial credit information database. It seeks to:

establish a mechanism to share enterprise environmental information, which should provide a basis for loan and investment decisions of the financial institutions;

to clarify the requirements of information disclosure and other regulatory arrangements for green bond issuance;

to encourage rating agencies to evaluate the green performance of the issuers and the greenness of the projects, as well as the impact of environmental costs on creditworthiness, and to disclose such information separately in credit rating reports;

to gradually establish and improve the mandatory environmental information disclosure system for listed enterprises and bond issuers;

to encourage third-party professional organisations to participate in the collection, research and release of corporate environmental information and analytical reports (PBOC 2016).

The guidelines also explore more stringent regulatory and market instruments such as environment pollution liability insurance to manage environmental risks, in implementing the BRI and other overseas investment projects (ibid.). 


\subsection{The implementation of the Green Credit Policy by major Chinese banks}

According to the IFC, the 21 largest Chinese banks have adopted E\&S risk management practices, and green financing projects now make up approximately 10 per cent of the portfolios of these banks (IFC 2018b). There are no data on the portfolio of BRI green financing, but it is useful to examine the performance of the key funders of BRI projects, that is, the China Development Bank (CBD) and the Export-Import Bank of China (China Exim Bank), in order to understand how these policies are implemented in BRI countries.

The CDB is the largest development bank in the world in terms of capital. At the end of 2017, the CDB continued to maintain the leading position in supporting China's overseas financing and investment efforts, with a balance of foreign currency loans equivalent to US\$261.7bn and a balance of cross-border RMB loans of RMB83.4bn (CDB 2018). With US\$17.6bn BRI loans in 2017, the CDB provided funding to support infrastructure connectivity, production capacity, and equipment manufacturing cooperation, financial cooperation, and overseas industrial parks (ibid.). It has developed collaboration with over 100 overseas central banks, development banks, and commercial banks. The CDB has adopted the GCG and joined some related international initiatives, such as the UNEP Finance Initiative. The CDB's environmental and social policy requests that borrowers abide by the laws and regulations of the host country, and that loan applications must be accompanied by an environmental impact assessment by an independent third party. Environmental standards and costs must be included in the loan agreement and the environmental impact assessment should be conducted when the project is completed (Greenovation Hub 2016).

The China Exim Bank is a policy bank with the mandate to promote steady growth, structural adjustment, and international economic cooperation. As early as 2007, it issued the Guidance on Environmental and Social Assessment of Lending Projects and in 2012, the bank set the strategic goal to become a pioneer in green finance in its 12th Five-Year Plan (Development Research Center of the State Council and the Export-Import Bank of China 2019). In 2015, the bank issued Guidance on Green Credit in accordance with the Key Performance Indicators of Green Credit Implementation requested by the CBRC. In 2017, the bank released the Rules on Advisory Business for Carbon Assets, Operational Procedures on Due Diligence, and Operational Rules on Loan Risk Monitoring and Management, aiming at enhanced environmental and social risk management (ibid.). In 2018, the bank adopted new lending policies for coal, chemicals, non-ferrous metals, and thermal power to restrict lending to industries with major environment and social risks. To date, the BRI loans of the China Exim Bank reached RMB 1tn with around RMB 250bn rated as green credit (ibid.). 
Table 2 Policies of development banks

$\begin{array}{llll}\begin{array}{l}\text { China } \\ \text { Development } \\ \text { Bank }\end{array} & \text { China Exim Bank World Bank } & \begin{array}{l}\text { Asian } \\ \text { Development } \\ \text { Bank }\end{array} & \begin{array}{l}\text { African } \\ \text { Development Bank }\end{array} \\ \end{array}$

\section{Environmental and}

social assessment Yes

(ESA)

\section{Social and}

environmental

standards by

industry

$\begin{array}{lllll}\text { Yes } & \text { Yes } & \text { Yes } & \text { Yes } & \text { Yes }\end{array}$

\section{Consistent with the environment, society, and laws \\ of the host country} Yes Effective restraints Effective restraints in some industries in some industries Yes

Standards for such industries as agriculture and energy
Requirements for agriculture, education, energy infrastructure, etc.

\begin{tabular}{|c|c|c|c|c|c|}
\hline $\begin{array}{l}\text { Consistent with } \\
\text { international } \\
\text { environmental and } \\
\text { social standards }\end{array}$ & $\begin{array}{l}\text { Encourage, } \\
\text { require to deliver } \\
\text { the results } \\
\text { that reach the } \\
\text { standards in } \\
\text { essence }\end{array}$ & $\begin{array}{l}\text { Encourage, } \\
\text { require to deliver } \\
\text { the results } \\
\text { that reach the } \\
\text { standards in } \\
\text { essence }\end{array}$ & Yes & Yes & Yes \\
\hline $\begin{array}{l}\text { Information } \\
\text { disclosure }\end{array}$ & $\begin{array}{l}\text { Annual reports } \\
\text { and sustainable } \\
\text { development } \\
\text { reports }\end{array}$ & $\begin{array}{l}\text { Annual reports } \\
\text { and sustainable } \\
\text { development } \\
\text { reports }\end{array}$ & $\begin{array}{l}\text { Information access } \\
\text { policy }\end{array}$ & $\begin{array}{l}\text { Public } \\
\text { commutation } \\
\text { policy }\end{array}$ & $\begin{array}{l}\text { Information } \\
\text { disclosure and open } \\
\text { policy }\end{array}$ \\
\hline Appeals system & Not available & Not available & Yes & Yes & Yes \\
\hline Third-party audit & Not available & Not available & Yes & Yes & Yes \\
\hline $\begin{array}{l}\text { Audit, supervision, } \\
\text { and management } \\
\text { in project } \\
\text { construction and } \\
\text { operation }\end{array}$ & $\begin{array}{l}\text { Requirement for } \\
\text { self-reporting }\end{array}$ & $\begin{array}{l}\text { Requirement for } \\
\text { self-reporting }\end{array}$ & Planning & $\begin{array}{l}\text { Included in the } \\
\text { ESA }\end{array}$ & Included in the ESA \\
\hline $\begin{array}{l}\text { Negative/exclusion } \\
\text { list }\end{array}$ & Planning & $\begin{array}{l}\text { New policy } \\
\text { enacted in } 2018\end{array}$ & Yes & Yes & Yes \\
\hline
\end{tabular}

Source Adapted and partially translated from Greenovation Hub (2016).

\section{Capacities for Chinese companies to follow high environmental and social standards 5.1 The general picture \\ According to a United Nations Development Programme (UNDP) study based on 543 responses from Chinese enterprises invested in BRI countries, and the feedback from 38 stakeholders from host countries, sustainable development concepts are acknowledged and practised by most Chinese enterprises, but the capacity, implementation, and results can still be improved (UNDP 2017).}


With regard to social performance, over half of the surveyed companies had conducted social impact assessments before implementing their projects. Companies have also tended to attach importance to philanthropic activities. Complying with local laws and regulations on employment is the standard for establishing labour relations and some opt for more proactive communication-based solutions to deal with labour disputes. However, some enterprises have not conducted independent social impact assessments. Some enterprises also have problems with the limited effectiveness of their charitable giving. Cultural differences and unfamiliarity with local customs have been major barriers for establishing good labour relations (ibid.). Chinese companies' corporate social responsibility (CSR) activities in Myanmar, for instance, show that companies are extremely short of people who understand local communities.

According to the UNDP study, in regard to environmental issues, the majority of Chinese enterprises have conducted environmental impact assessments according to the requirements of the host countries, and generally by third-party organisations. The stringency of these assessments and their impacts on project design varies across firms and countries. Most companies have adopted measures to reduce emissions, pollutants, and intentionally control the environmental impact throughout the whole product life cycle. Nevertheless, Chinese enterprises must control their environmental impact more systematically and scientifically, and track and document relevant data and information within their business operations (ibid.).

\subsection{Capacity-building efforts}

The awareness and will of Chinese companies to build up the capacity to respond to government policy guidance and better manage overseas risks has been increasing rapidly. Contractors are a group of important players in BRI infrastructure projects. From 2013 to 2018, the turnover of contracted projects conducted by Chinese firms reached US $\$ 400 \mathrm{bn}$ (Belt and Road Portal 2019b). The China International Contractors Association (CHINCA) is the national organisation formed in 1988 by Chinese international project investors, contractors, labour service companies, and related service providers, with over 1,500 members operating in 190 countries (CHINCA n.d.). Over the last few years, CHINCA has been actively strengthening industry self-discipline and capacity building, issuing industry reports and compliance guidance, and holding training courses. For instance, in order to enhance the awareness and capacity of companies to engage and communicate with local communities, CHINCA released the Handbook on Community Engagement for Chinese Contractors in May 2018 and it has been holding training programmes on this topic (CHINCA 2019a). CHINCA has also been actively collaborating with MDBs to host seminars since early 2018 and has been promoting joint funding between its members and the MDBs. 
It is also important to observe the transition of Chinese contractors in their business models for BRI projects. CHINCA has also been promoting the transition of contractors to investors and developers, changing from the EPC (Engineering Procurement Construction) model to BOT (Build-Operate-Transfer) models (CHINCA 2019b). In general, for the BOT model, the host-country government will specify the quality and quantity of utility services such as electricity and ensure the return of the company with an agreed pricing mechanism. For the EPC model, the contractor will deliver the design, procurement, and construction of the project within a fixed budget on the standards agreed with the owner. The key difference between the two is that with the BOT model, companies could pursue higher standards and internalise the increased costs, but with the EPC model, standards are limited within the fixed budget. This difference plays a key role in the capacitybuilding efforts of Chinese companies to pursue higher standards. ${ }^{3}$

Some Chinese companies have taken the lead in aligning themselves with high international standards in order to attract international funding and promote the image of international business operations. China Three Gorges South Asia Investment Ltd (CSAIL) is a company incorporated by a major Chinese state-owned enterprise, the Three Gorges Corporation, the International Finance Corporation of the World Bank Group (IFC), and the Silk Road Fund. With leading technical and engineering capacity in hydro- and wind power projects, the company is also committed to high international environmental and social standards for power projects under the China-Pakistan Economic Corridor (CPEG) umbrella. In 2017, CSAIL issued its Health Safety Social and Environmental Management System (internal document) which combined the E\&S systems of the IFC, China, and the host country, Pakistan. With 20 frameworks and eight standard operating procedures, the system covers a wide range of safeguards on safety, environment, society, and health. To date, all CSAIL power projects, with the BOT model, have adopted these standards. With the continued efforts of CSAIL in securing compliance by all contractors, the projects received high consideration from the IFG and local communities. ${ }^{4}$

Smaller Chinese companies could also be encouraged to adopt higher standards with funding incentives from international financial institutions. In 2017, the EBRD gave a loan to a Chinese private company for the first time, sending positive signals to Chinese companies willing to pursue higher standards. The EBRD gave a US\$52m loan to Angel Yeast Egypt, which is fully owned by the Chinese firm Angel Yeast, to finance the construction of new production facilities and a modern wastewater treatment plant in an area of Istanbul that has a high level of poverty and unemployment. Over 200 jobs will be created, while 300 new and current workers will receive in-depth technical training (Zgherib 2018). For the EBRD, Angel Yeast met its E\&S policy and performance requirements and it is willing to give loans to other Chinese investors that can meet these high standards. ${ }^{5}$ 


\section{Main findings}

As China is shifting to green development, it is paying increasing attention to a green BRI. Chinese companies are the key players to deliver infrastructure projects for the BRI. Their awareness and capacity are building up with increasing domestic and overseas pressure and incentives. The progress is evident but there are still gaps to cover.

\subsection{Continuous progress in Chinese policy guidance and regulatory} pressure is expected in the face of complex environmental and social risks Chinese ministries have been actively making policies and regulations to guide companies to improve environmental and social safeguard measures. The real challenge now is to ensure that high-level guidelines from regulators can be translated into substantive investor and contractor operational improvements. Current policies request investors to abide by local laws and regulations and encourage the adoption of international standards. In the case where host-country regulations and standards are very low or unestablished, Chinese companies could use Chinese standards which may be higher, but not as high as international ones. However, international NGOs and local communities would judge the projects according to the high standards practised by other international investors, and would not compromise their requirements just because the total budget of the project might be too low for the contractor to practise the higher standards. In many cases, opposition from international NGOs and local communities pose major risks to the projects.

\subsection{Strategic planning and regulation capacity in the host country is also critical}

Host-country development strategies and regulations play a key role in determining not only project standards but also the employed business model of the project, thus fundamentally influencing the environmental and social impacts throughout its life cycle. For instance, it is the host country that makes decisions on building coal-fired plants or clean energy plants in its energy strategy, and therefore their awareness and capacity to make an energy development strategy that aligns with their $\mathrm{CO}_{2}$ emission commitment under the Paris Agreement is of significance.

\subsection{Continued efforts are expected from the banks to play a more engaging role in the monitoring of E\&S policy implementation}

China's major banks are leading in green finance in emerging economies, and are converging with MDBs in E\&S safeguards. The enhanced regulatory details in the E\&S safeguards and information disclosure represent an important opportunity to improve on these standards across BRI projects. However, the normal practice of Chinese banks, which rely more on self-reporting, in contrast to the on-site monitoring and inspection practised by MDBs, might not be a measure strong enough to help companies manage social and environmental risks successfully.

\subsection{Chinese companies face more challenges in management and communication capacity than in technical capacity}

Chinese companies have been used to relying on local governments to deal with local communities, and many have not realised the need to 
acquire a social contract from local people. Therefore, companies have tended to overemphasise building a relationship with local governments but neglected consulting with local communities, NGOs, and the media, who have ever-increasing demands for environmental protection and labour benefits. IFG officials have pointed out that a lot of the conflicts between companies and the local people have been caused by small things in the eyes of Chinese managers. The companies have been realising these concerns but they face a shortage of qualified staff trained in the local language and cross-cultural communication. This demands greater effort to build up this capacity.

\subsection{The right business climate is a key factor to ensure that pressures and incentives are aligned}

Joint financing with international financial institutions and private investors will help prevent environmental and social hazards. However, the key challenge for investing in the infrastructure in developing countries is that very limited projects are considered bankable for MDBs and private investors, as the low private participation rate shows. In many countries, connecting capital available for green investment with investment opportunities is hampered by investment barriers, market failures, and policy misalignments. To overcome them, governments have a key role to play to strengthen domestic frameworks for economic, investment, and climate policies, to ensure that they are mutually supportive, and ultimately to improve the risk-return profile of green investment projects (OECD 2017). It is important for Chinese and international investors to work out the right business models with the host country for BRI projects.

\section{Recommendations}

Now a clearer picture has been established of the three key aspects centred around the decision-making of Chinese companies in adopting higher standards and good international practices: progress and gaps in pressure, incentives, and capacity. The key stakeholders including the Chinese government, Chinese companies, host countries, and international institutions could work in a more coordinated way to achieve the goal of a greening BRI.

\subsection{Making the pressure more effective}

Based on the momentum of policy guidance, Chinese ministries need to make continued efforts to promulgate more detailed regulations and performance indicators to give companies clearer signals. For instance, to require information disclosure and open consultations with local communities at an early stage of the project.

International organisations should give more technical assistance on economic analysis and strategic planning to the developing countries along the Belt and Road. Objective economic analysis will help participating countries choose the kinds of investments and reforms that will best meet their development needs. 
The newly launched BRI International Green Development Coalition and the big data platform could play constructive roles in promoting cooperation among governments and key stakeholders. These frameworks could provide a way for investors (public and private), recipients (both governments and domestic stakeholders), and other partners to share information on what standards they use and how they operationalise them. This could create a process to promote upward convergence of standards across the BRI over time. These will need to be multilateral and transnational in nature and co-owned by different countries and stakeholder groups, although there would obviously be a critical convening role for China. Such an outcome would be in line with the interests of all stakeholders and China now has the technical capacity to provide this public good.

\subsection{Enhance joint financial and reputational incentives}

To enhance financial incentives to companies, clear and transparent BRI financing rules will be a key solution to both insufficient financing incentives for investors and the low rate of financing participation from MDBs. Some conditions are already there for the joint development of a set of rules and standards. In May 2017, China's Ministry of Finance, the World Bank, and five other MDBs jointly signed an MoU on strengthening cooperation on the BRI to support the 2030 Agenda and the Paris Agreement. At the April 2019 Belt and Road Forum, a number of MDBs, alongside the Chinese Ministry of Finance, announced the creation of the Multilateral Cooperation Center for Development Finance, with the AIIB serving as secretariat. These and other platforms provide an important opportunity for fomenting further collaboration.

Governments and international institutions could also harmonise efforts to promote the investment climate of developing countries and to reduce the risks for potential investors, particularly private investors. Reforms include improving the legal protection of investment and the consistency of the regulations. Developing countries participating in the BRI need the ambition to substantially improve their environment for sustained investment.

International organisations could provide more public goods to help the regulators of participating countries and incentivise investors. The IFC's member-led Sustainable Banking Network, with 34 members including China, provides strategic and technical how-to guidance to help institutions to systematically integrate sustainability considerations into business strategy and operations (IFC 2018a). The World Wildlife Fund for Nature (WWF) suggested the development of a Sustainable Infrastructure Opportunity Index, to provide a guiding framework to prioritise BRI countries with sustainable infrastructure investment opportunities based on both infrastructure drivers and the environmental governance performance of various BRI countries (WWF 2018).

Both the Chinese government and international organisations could jointly enhance demonstrations of high standards and good practices. 
For investors, it is hard to understand the abstract concepts but easy to follow practices that could bring them higher benefits. They need confidence in business cases that could satisfy high standards, business sustainability, and public interests. While the Chinese government is trying to highlight the good practices of the BRI over the past six years, international organisations could help this process with their knowledge, experience, and comparative perspectives. For example, experience of cases such as that of CSAIL, the largest clean energy investor in Pakistan, and the IFC, the largest private investment institution in the world, joining hands to conduct an investment that could provide huge support to economic growth and the improvement of livelihoods in Pakistan. Similarly, the EBRD could demonstrate how an MDB could support medium and small investors to reach high E\&S standards.

\subsection{Multiple measures need to be taken for the capacity building of companies}

Awareness of environmental and social hazards and the willingness to make efforts to meet standards is crucial. In addition, measures need to be taken to target the key challenges. Companies need to optimise internal management including decision-making, monitoring, performance evaluation, and the employment of more professionals on compliance and E\&S management. In response to the shortage of talent for effective communication with local communities, more effective measures should be adopted to promote domestic education that equips a greater number of graduates with language skills and cross-cultural understanding. Hiring more local employees would also aid better local engagement. For SOEs, a more flexible employment mechanism could be explored in overseas corporations. The market for consulting services on international rules should be further developed. Chinese business associations and environmental NGOs should be promoted and encouraged to operate overseas and play supporting and monitoring roles.

In conclusion, the BRI is a great development opportunity for those countries short of infrastructure and funding. However, BRI investment could bring about mixed environmental and social impacts. Investor guidance, regulation, and support will be critical in meeting the high environmental and social standards necessary to achieve the sustainable development of BRI countries and the world. The Chinese government, host-country governments, as well as international organisations and financial institutions all have important roles to play.

\section{Notes}

* This IDS Bulletin is supported by the Center for International Knowledge on Development's (CIKD) China-UK Partnership Programme on Knowledge for Development.

+ I would like to express my gratitude to Thomas Hale of the University of Oxford for his contributions and input in the writing of this article. I would also like to show appreciation to the two peer reviewers, each of whom provided valued critique. 
1 Jiang Xiheng, Vice President, Center for International Knowledge on Development (CIKD), China and $\mathrm{PhD}$ candidate, Institute of South-South Cooperation and Development, Peking University.

2 The content of this part is based on the study of relevant documents and the author's interviews with IFG and EBRD officials.

3 Concluded from the interviews with a dozen Chinese companies.

4 Based on the field study and interviews with staff from the IFC and CSAIL.

5 Based on interviews with EBRD officials.

\section{References}

ADB (2017) Meeting Asia's Infrastructure Needs, Manila: Asian Development Bank, www.adb.org/sites/default/files/publication/ 227496/special-report-infrastructure.pdf (accessed 13 August 2019)

Belt and Road Portal (2019a) Foint Communique of the Leaders' Roundtable of the 2nd Belt and Road Forum for International Cooperation, 27 April, https://eng.yidaiyilu.gov.cn/qwyw/rdxw/88230.htm (accessed 13 August 2019)

Belt and Road Portal (2019b) The Belt and Road Initiative: Progress, Contributions and Prospects, 22 April,

https://eng.yidaiyilu.gov.cn/zchj/qwfb/86739.htm (accessed 13 August 2019)

Belt and Road Portal (2018) Action Plan on Standardization Connectivity 2018-2020, 11 January, www.yidaiyilu.gov.cn/zchj/qwfb/43480.htm (accessed 13 August 2019)

Belt and Road Portal (2017a) Code of Conduct for Overseas Investment and Management of Private Enterprises, 18 December, www.yidaiyilu.gov.cn/zchj/zcfg/40059.htm (accessed 13 August 2019)

Belt and Road Portal (2017b) Guidance on Promoting Green Belt and Road, 8 May, https://eng.yidaiyilu.gov.cn/zchj/qwfb/12479.htm (accessed 13 August 2019)

Belt and Road Portal (2017c) The Belt and Road Ecological and Environmental Cooperation Plan, 14 May, https://eng.yidaiyilu.gov.cn/zchj/ qufb/13392.htm (accessed 13 August 2019)

Belt and Road Portal (2017d) Vision and Actions on Energy Cooperation in Fointly Building Road Economic Belt and 21st-Century Maritime Silk Road, 16 May, https://eng.yidaiyilu.gov.cn/zchj/qwfb/13754.htm (accessed 13 August 2019)

CDB (2018) Annual Report, Beijing: China Development Bank, www.cdb.com.cn/gykh/ndbg_jx/2018_jx/ (accessed 13 August 2019)

China Banking and Insurance Regulatory Commission (2019) Green Credit Guidance, Beijing: China Banking and Insurance Regulatory Commission, www.cbrc.gov.cn (accessed 13 August 2019)

CHINCA (n.d.) President's Speech, China International Contractors Association, www.chinca.org/CICA/PresidentSpeech/ Detail/17102414503811 (accessed 13 August 2019)

CHINCA (2019a) Notice on Holding a Series of Training on Sustainable Development of Foreign Contracted Engineering Industry: Community Development Manager Training Class, China International Contractors 
Association, 22 July, www.chinca.org/CICA/info/19072214220411 (accessed 13 August 2019)

CHINCA (2019b) The Contractor Will Cooperate with the AIIB to Hold a Seminar on 'High-Quality, Sustainable Infrastructure Interconnection Cooperation Opportunities', China International Contractors Association, 23 April, www.chinca.org/CICA/info/19042316123811 (accessed 13 August 2019)

Development Research Center of the State Council and the ExportImport Bank of China (2019) Green Finance for the Belt and RoadChina's Approaches and Practices, Working Paper, Beijing: Development Research Center of the State Council and the Export-Import Bank of China, www.xinhuanet.com//money/2019-04/23/c_1210117043.htm (accessed 10 October 2019)

Equator Principles Association (2019) EP Association Members and Reporting, https://equator-principles.com/members-reporting/ (accessed 13 August 2019)

Fa, Y.J. (2012) Notice to Issue Green Credit Guidelines, Beijing: China Banking Regulatory Commission, www.cbrc.gov.cn/chinese/home/ docView/127DE230BC31468B9329EFB01AF78BD4.html (accessed 13 August 2019)

Green Finance (2019) 27 Institutions Around the World Signed the 'One Belt, One Road' Green Investment Principles, https://mp.weixin.qq.com/s/BFaTVKEjJIkWizRAlL5DdA (accessed 13 August 2019)

Greenovation Hub (2016) China's Development Financing under 'The Belt and Road' Initiative - National Development Bank and its Environmental and Social Risk Management, Beijing: Greenovation Hub, www.ghub.org/wp-content/uploads/2017/04/NDB_201610.pdf (accessed 13 August 2019)

IFG (2018a) Sustainable Banking Network (SBN) Global Progress Report, Washington DC: Environmental, Social and Governance Department, International Finance Corporation, www.ifc.org/wps/ wcm/connect/ae589874-6578-4ca9-9b3c-caef967ed52c/SBNGlobalProgressReport.pdf?MOD=AJPERES\&CVID $=\mathrm{md0nvNj}$ (accessed 13 August 2019)

IFG (2018b) Sustainable Banking Network (SBN) Country Progress Report: Addendum to SBN Global Progress Report: China, Washington DC: Environmental, Social and Governance Department, International Finance Corporation, www.ifc.org/wps/wcm/connect/9e027b2bcd9f-4a4a-9924-4178fd90bd8e/SBN+Country+Progress+Report++ China.pdf ?MOD=AJPERES\&CVID $=$ m745LiT $($ accessed 13 August 2019)

International Cooperation and Exchange Center of the Ministry of Ecology and Environment (2019) Green Has Become the Background of the 'Belt and Road' Construction: The Second 'One Belt, One Road' International Cooperation Summit Forum Green Development Achievements Overview, 6 May, www.mepfeco.org.cn/dtxx/xwdt/201905/ t20190506_702025.html (accessed 13 August 2019) 
Littlecott, C. and Hawkins, J. (2019) Clean Energy Not Coal: Citizens'Views on Foreign Investment in Six Countries, London: E3G, www.e3g.org/docs/Clean_Energy_not_Coal_E3G_YouGov_ Polling_Report_2019-04-24.pdf (accessed 10 October 2019)

McKinsey Global Institute (2016) Bridging Global Infrastructure Gaps, New York NY: McKinsey and Company, www.mckinsey.com/industries/ capital-projects-and-infrastructure/our-insights/bridging-globalinfrastructure-gaps (accessed 13 August 2019)

MEE (n.d.) Green Silk Road Envoy Programme, Beijing: Ministry of Ecology and Environment, www.mepfeco.org.cn/dtxx/xwdt/201904/ P020190420696633377564.pdf (accessed 13 August 2019)

Ministry of Foreign Affairs of the People's Republic of China (2019a) Xi finping Attends the Opening Ceremony of the Second Belt and Road Forum for International Cooperation (BRF) and Delivers Keynote Speech, 26 April, www.fmprc.gov.cn/mfa_eng/zxxx_662805/t1659374.shtml (accessed 13 August 2019)

Ministry of Foreign Affairs of the People's Republic of China (2019b) Xi Finping Chairs and Addresses the Leaders' Roundtable of the Second Belt and Road Forum for International Cooperation (BRF), 27 April, www.fmprc.gov.cn/mfa_eng/zxxx_662805/t1659377.shtml (accessed 13 August 2019)

Ministry of Foreign Affairs of the People's Republic of China (2019c) List of Deliverables of the Second Belt and Road Forum for International Cooperation, 27 April, www.fmprc.gov.cn/mfa_eng/zxxx_662805/ t1658767.shtml (accessed 13 August 2019)

OECD (2017) 'GREEN Action Task Force: Discussion Note on Infrastructure Investment and the Low-Carbon Transition: Implications of the Belt and Road Initiative on the Eurasia Region', Annual Meeting of the GREEN Action Task Force, Almaty, 26-27 October, Organisation for Economic Co-operation and Development, www.oecd.org/env/outreach/EAP $\% 20$ RD\%282017\%292\%20Belt\%20and\%20Road.pdf (accessed 13 August 2019)

PBOC (2016) Guidelines for Establishing the Green Financial System, People's Bank of China, 2 September, www.pbc.gov.cn/ english/130721/3133045/index.html (accessed 13 August 2019)

Pilling, D. (2019) 'It is Wrong to Demonise Chinese Labour Practices in Africa', Financial Times, 3 July, www.ft.com/content/6326dc9a-9cb811e9-9c06-a4640c9feebb (accessed 13 August 2019)

State Council Information Office of the People's Republic of China (2016) 'President Xi Calls for Building "Green, Healthy, Intelligent and Peaceful” Silk Road', 23 June, www.scio.gov.cn/32618/Document/1481477/1481477.htm (accessed 13 August 2019)

UNDP (2017) Report on The Sustainable Development of Chinese Enterprises Overseas: Supporting the Belt and Road Regions to Achieve the 2030 Agenda for Sustainable Development, New York NY: United Nations Development Programme, www.cn.undp.org/content/china/ en/home/library/south-south-cooperation/2017-report-on-the- 
sustainable-development-of-chinese-enterprise.html (accessed 13 August 2019)

World Bank (2017) Private Participation in Infrastructure, Washington DC: World Bank, www.worldbank.org/en/country/singapore/ publication/private-participation-in-infrastructure (accessed 13 August 2019)

World Bank Group (2019) Belt and Road Economics: Opportunities and Risks of Transport Corridors, Washington DC: World Bank, https://openknowledge.worldbank.org/bitstream/handle/10986/ 31878/9781464813924.pdf? sequence $=4 \&$ isAllowed $=\mathrm{y}$ (accessed 13 August 2019)

WWF (2018) Greening the Belt and Road Initiative: WWF's Recommendations for the Finance Sector, Gland: World Wildlife Fund for Nature, www.wwf.org.uk/sites/default/files/2018-04/greening-the-belt-androad-initiative.pdf (accessed 13 August 2019)

Xueqing, J. (2016) 'CBRC Pushes Green Finance', China Daily, 6 September, www.cbrc.gov.cn/chinese/home/docView/ D5394164CCBF47F8AE076FF0924A7612.html (accessed 10 October 2019)

Xinhua News (2017) 'Full Text of President Xi's Speech at Opening of Belt and Road Forum', 14 May, www.xinhuanet.com/english/2017-05/14/c_136282982.htm (accessed 13 August 2019)

Xinhua News (2015) 'Vision and Actions on Jointly Building Silk Road Economic Belt and 21st-Century Maritime Silk Road', 30 March, https://eng.yidaiyilu.gov.cn/qwyw/qwfb/1084.htm (accessed 13 August 2019)

Zgherib, N. (2018) EBRD Supports Chinese Investment in Egypt with Loan to Angel Yeast, London: European Bank for Reconstruction and Development, www.ebrd.com/news/2018/ebrd-supportschinese-investment-in-egypt-with-loan-to-angel-yeast.html (accessed 13 August 2019) 